\title{
International \\ Orthopaedics
}

(C) Springer-Verlag 1998

\section{Current concepts}

\section{Growth factors in bone}

\author{
E. Solheim \\ Section of Orthopaedics, Deaconess University Hospital, Haraldsplass, Bergen, Norway
}

Accepted: 9 January 1998

Summary. Bone contains several growth factors, including bone morphogenetic proteins (BMPs), transforming growth factor beta (TGF- $\beta$ ), insulin-like growth factors I and II (IGF-I and IGF-II), platelet derived growth factor (PDGF) and basic and acidic fibroblast growth factor ( $b F G F$ and aFGF). Spatial and temporal variations in the expression and secretion of the various growth factors have been demonstrated in osteoblastic cultures and in various experimental and clinical in vivo models, including fracture healing in humans. Local application of various growth factors influences proliferation, differentiation and protein synthesis in osteoblastic cultures and bone formation in different animal models, including experimental fractures and skeletal defects. The $B M P$ s are the only growth factors known to provoke bone formation heterotopically by making undifferentiated mesenchymal cells differentiate into osteoblasts (osteoinduction). BMPs and other growth factors, soon to become commercially available for clinical use, need a delivery system for their sustained release, as the factors are otherwise rapidly absorbed. Some existing systems inhibit bone formation by inducing chronic inflammation or physically by unresorbed carrier obstructing bone formation. New delivery systems are being investigated.

Résumé. L'os contient plusieurs facteurs de croissance notamment: la protéine morphogénétique osseuse (BMPs), le facteur de croissance bêta (TGF-B), les facteurs de croissance insuline-like I et II (IGF-I et IGF-II), le facteur de croissance plaquettaire

Reprint requests to: E. Solheim, Section of Orthopaedics, Deaconess Hospital, Haraldsplass, University of Bergen, N-5009 Bergen, Norway

No benefits in any form have been received or will be received from a commercial party related directly or indirectly to the subject of this article
(PDGF) et les facteurs de croissance fibroblastique basique et acide (bFGF et aFGF). Des variations spatiales et temporelles de la secrétion des différents facteurs de croissance ont été démontrées dans les cultures ostéoblastiques et dans différent modèle expérimental et clinique notamment, la consolidation de fracture chez l'homme. L'application locale des différents facteurs de croissance influence la prolifération, la différenciation et la synthèse protéique dans les cultures d'ostéoblastes ainsi que la formation osseuse dans les différents modèles animaux avec notamment fracture expérimentale et perte de substance squelettique. Les BMPs sont les seuls facteurs de croissance connus pour provoquer une formation d'os hétérotopique par différenciation en ostéoblastes des cellules mésenchymateuses indifférenciées (ostéoinduction). Les BMPs et les autres facteurs de croissance seront bientôt commercialement disponibles pour l'usage clinique ce qui nècessitera des systèmes de distribution particuliers pour leur préservation. Il existe déjà des systèmes inhibant la formation osseuse de façon physique ou en induisant une inflammation chronique.

\section{Introduction}

In 1938, Levander found that an acid alcohol extract of bone and callus induced heterotopic cartilage and bone when injected intramuscularly in rabbits and concluded that bone regeneration takes place as the result of some specific bone-forming substance activating the nonspecific mesenchymal tissue [38]. However, the study of growth factors in bone was hampered because these factors are sequestered in abundant extracellular matrix which has to be removed before further purification can be done. Mod- 
ern laboratory techniques, including recombinant DNA technology, have made it possible to identify several bone growth factors in recent years, including bone morphogenetic proteins (BMPs), insulin-like growth factors I and II (IGF-I and IGF-II), transforming growth factor beta (TGF- $\beta$ ), platelet derived growth factor (PDGF) and basic and acidic fibroblast growth factor (bFGF and aFGF).

Growth factors are polypeptides that are generally synthesised by specific tissue where, in very low concentrations, they act as local regulators of cell function. Most growth factors are released as high molecular weight precursors which are split by proteolysis and produce active factors which are generally of low molecular weight. Growth factors elicit their action by binding to specific large transmembrane receptors on the cell surface of the target cell. Binding to the extracellular domain of the receptor triggers the intracellular domain, which generally activates a protein kinase. The kinase cascade activates transcription of a gene into mRNA, which is then translated into proteins to be used within the cell or exported [71]. Generally, the number of active receptors of a cell decreases when the growth factor is present in excess (down regulation), whereas it increases when there is a deficiency (up regulation).

Most of the knowledge about the effect of growth factors on osteogenic cells derives from studies on cultures of osteoblast-like cells from embryonic bone tissue of the rat or mouse, or from osteosarcoma cell lines. Less is known about the physiological effect of the different growth factors in vivo, but some studies have been done on immunolocalisation and expression of different growth factors in fracture healing (Table 1).

\section{BMPs}

Urist believed that osteoinduction by demineralised bone [72], was caused by a contained factor which he named bone morphogenetic protein (BMP), and in 1979 the group isolated an extract of osteoinductive glycoproteins [73]. In 1988, Wozney et al. extracted $40 \mu \mathrm{g}$ inductive proteins from $40 \mathrm{~kg}$ of bone. Chromatography showed that the extract contained several proteins, but further purification was not possible. The proteins were tryptinized, cDNA was cloned, recombinant human peptides were made in Chinese hamster ovary $(\mathrm{CHO})$ cells and three proteins were demonstrated, BMP-1, BMP-2A and BMP-3 [80]. Later, more BMPs were identified, and there are at present at least 15. The BMPs, except BMP-1, are part of the TGF- $\beta$ supergene family. They are important in both extraskeletal and skeletal organogenesis, bone generation and regeneration, and are involved in certain disease processes; mutations of their genes may cause developmental anomalies [54].

BMP receptors have been identified [50], and upregulation of the expression of BMP receptors during bone formation in embryonic development and fracture healing have been demonstrated [34]. A large

Table 1. Growth factors and fracture healing

\begin{tabular}{|c|c|c|c|c|}
\hline Stage of healing & Growth factor & Source, localisation and action & \multicolumn{2}{|c|}{ References } \\
\hline \multirow{7}{*}{$\begin{array}{l}\text { Immediate } \\
\text { injury } \\
\text { response }\end{array}$} & BMP-2/4 & $\begin{array}{l}\text { Found in mesenchymal cells in hematoma and cambium layer of periosteum } \\
\text { adjacent to fracture. BMP- } 4 \text { mRNA is present in osteoprogenitor cells of the }\end{array}$ & \multicolumn{2}{|c|}{$[16,48]$} \\
\hline & & proliferating periosteum, the medullary cavity and the muscles near the fracture. & \multirow{2}{*}{\multicolumn{2}{|c|}{$[14,37]$}} \\
\hline & TGF- $\beta$ & Released by platelets and inflammatory cells into the fracture hematoma. & & \\
\hline & & Stimulates proliferation of mesenchymal cells in cambium layer of periosteum. & \multirow{3}{*}{\multicolumn{2}{|c|}{$[14,17]$}} \\
\hline & PDGF & $\begin{array}{l}\text { Released by platelets and inflammatory cells into the fracture hematoma. } \\
\text { Found in macrophages close to the periosteum } 2 \text { days post-fracture, decreases }\end{array}$ & & \\
\hline & & $\begin{array}{l}\text { from day } 3 \text {. Stimulates proliferation of mesenchymal cells in cambium layer } \\
\text { of periosteum. }\end{array}$ & & \\
\hline & $\mathrm{aFGF}$ & $\begin{array}{l}\text { Found in cells of the expanded cambium layer and associated with rapid increase } \\
\text { in mesenchymal cells. }\end{array}$ & & [17] \\
\hline \multirow[t]{3}{*}{$\begin{array}{l}\text { Intramembranous } \\
\text { bone formation }\end{array}$} & BMP-2/4 & $\begin{array}{l}\text { Found in osteoblasts lining primitive (woven) bone by } 6 \text { days after fracture. } \\
\text { Decreases as the bone matures. }\end{array}$ & & [16] \\
\hline & TGF- $\beta$ & $\begin{array}{l}\text { Found in proliferating mesenchymal cells, in osteoblasts lining new bone } \\
\text { and in the matrix. }\end{array}$ & & [37] \\
\hline & PDGF & Released by platelets and stimulates intramembranous bone formation. & & [14] \\
\hline \multirow[t]{4}{*}{ Chondrogenesis } & BMP-2/4 & \multirow{4}{*}{\multicolumn{3}{|c|}{$\begin{array}{l}\text { Chondroid precursor cells stain intensly just prior to becoming immature chondrocytes. } \\
\text { Found in mesenchymal cells, young chondrocytes and mature chondrocytes. } \\
\text { Found in young chondroblasts at the edge of the cartilage mass replacing fibrous tissue. [17] } \\
\text { Synthesized by chondocytes, their precursors and macrophages. Stimulates chondrocyte [14] } \\
\text { proliferation and is probably important for chondrocyte maturation. }\end{array}$}} \\
\hline & TGF- $\beta$ & & & \\
\hline & IGF-I & & & \\
\hline & aFGF & & & \\
\hline \multirow{4}{*}{$\begin{array}{l}\text { Endochondral } \\
\text { ossification }\end{array}$} & BMP-2/4 & \multirow{4}{*}{\multicolumn{3}{|c|}{$\begin{array}{l}\text { Intense intracellular staining of osteoblasts lining the calcified cartilage matrix. } \\
\text { Found in the matrix surrounding hypertrophic chondrocytes. } \\
\text { Found in chondrocytes at the edge of the ossification front. } \\
\text { Probably produced by chondrocytes and is important for endochondral bone formation. }\end{array}$}} \\
\hline & TGF- $\beta$ & & & \\
\hline & TGF- $\beta$ & & & \\
\hline & bFGF & & & \\
\hline
\end{tabular}


number of binding sites for BMP-2 have been found not only on osteoblastic cells but also on various other normal cells and tumour cells [35].

Recombinant human BMP-2 in rat inactive demineralised bone matrix carrier implanted subcutaneously in rats induces cartilage by 5 days, some new bone by 7 days and an ossicle with marrow at 21 days [75]. When the concentration of BMP-2 is increased, bone formation is observed earlier and cartilage and bone are formed concurrently. The osteoinductive response by BMP-4 and BMP-5 seems to be weaker than that of BMP-2 [79]. Cartilage and bone formation is induced in athymic mice by $\mathrm{CHO}$ cells transfected with the murine BMP-6 gene [29] or BMP-4 gene [58].

The ability of implanted BMPs to induce heterotopic osteogenesis in primates is still not clear. Aspenberg et al. found that rhBMP-2 combined with demineralised bone induced heterotopic osteogenesis in squirrel monkeys, whereas demineralised bone alone did not [9]. However, the amount of induced bone was small. In a recent study, rhBMP-2 and bovine type I collagen implanted intramuscularly in squirrel monkeys resulted in an osteoinductive response that was small, inconstant and partly dependent on placing the implants close to the muscle aponeurosis [8].

Several BMPs, including BMP-2, BMP-3, BMP-4, BMP-6 and BMP-7 converted the differentiation pathway of different pluripotent mesenchymal cell lines into that of an osteoblast lineage [2, 3, 81]. BMP-7 (OP-1) can make different pluripotent mesenchymal cell lines differentiate into both chondroblastic and osteoblastic cells, depending on the stage and potential of the target cell [6]. Messenger RNAs for BMP-2 and BMP-4 are expressed in foetal rat calvarial osteoblasts as they differentiate in primary cultures prior to forming mineralised bone nodules coinciding with expression of osteocalcein, osteopontin and alkaline phosphatase [31]. BMPs have been shown to be involved in fracture healing (see Table 1) $[16,48]$.

Implanted rhBMP-2 enhances the healing of: (1) defects of the femur of rats [82] and sheep [28]; (2) defects of the mandible of rats (in combination with membranes) [41], dogs [70] and rhesus monkeys [18]; and (3) lumbar intertransverse process fusion in rabbits [55] and dogs [32]. Recombinant human BMP-7 (OP-1) enhances the healing of segmental ulnar defects in rabbits [24], dogs [23] and African green monkeys [25]. Recently, rhBMP-2 has been shown to stimulate the repair of bone and hyalin-like cartilage in experimental osteochondral defects in rabbits [57].

Recombinant human BMP-2 is currently being evaluated in clinical studies in humans for augmentation of the floor of the maxillary sinus to increase the bone height and allow the placement of dental implants. It is expected that in the next few years, rhBMPs in suitably delivery systems will be evaluated in clinical studies for a number of other indications in orthopaedic and cranio-maxillofacial trauma and disease.

\section{TGF- $\beta$}

The TGF- $\beta$ s are members of the TGF- $\beta$ superfamily. So far, five subtypes have been demonstrated. TGF$\beta 4$ is found in chickens, TGF- $\beta 5$ in amphibians. The TGF- $\beta$ s are $25 \mathrm{kDa}$ homodimers sharing 60 to $80 \%$ similarity in their amino acid sequence. TGF- $\beta$ s influence a variety of tissues, generally stimulating cells of mesenchymal origin and inhibiting cells of ectodermal origin [39]. TGF- $\beta$ is produced by osteoblasts and is stored in the bone matrix, making bone the largest reservoir of TGF- $\beta$ in the body [15]. Osteoblasts have the highest number of TGF- $\beta$ receptors [39].

TGF- $\beta$ s mediate tissue embryogenesis, normal cellular physiology, inflammation and tissue repair [27]. TGF- $\beta 1$ is found in the periosteum at an early stage in fractures, both in experimental fractures in animals [14] and clinically in humans [4]. TGF- $\beta 1$ enhances the proliferation of mesenchymal cells and osteoblasts in fractures as well as in experimental bone defects [10, 14, 65].

Whereas BMPs induce bone in heterotopic sites, stimulation of bone formation by TGF- $\beta$ depends on orthotopic application, for example, subperiosteal injection [65]. TGF- $\beta 1$ enhances the healing of experimentally created defects of the skull in rabbits [11, 47] and bone ingrowth in porous titanium rods [64] and tricalcium phosphate coated implants in dogs [40].

\section{PDGF}

PDGF is a dimer of two peptides, A and B, sharing $60 \%$ amino acid sequence homology. Dependent on the combination of peptides, the molecular weight varies between 28 and $35 \mathrm{kDa}$. PDGF-BB homodimer is more biologically active than the two other dimers. PDGF-BB and $A B$ act as systemic growth factors, whereas PDGF-AA acts as a local growth factor in bone. Normal human and rat bone cells express only the PDGF-A gene under unstimulated culture conditions, whereas osteosarcoma cells express both PDGF-A and B genes. Alpha2 macroglobulin binds PDGF and may act as a transport protein [21].

PDGF is synthesised by blood platelets, monocytes, macrophages and endothelial cells and influences most mesodermal cells. It increases DNA synthesis, cell replication, collagen and non-collagen protein synthesis in cultures of rat calvarial cells. The mitogenic effect, however, is not specific for cells of the osteoblastic lineage, as PDGF-BB also stimulates the replication of non-skeletal fibroblasts [1,21]. Two PDGF receptor subunits have been demonstrated, alpha and beta, and the two subunits form dimers in response to PDGF binding as part of the receptor activation process. PDGF-B polypeptide binds to both the alpha and beta subunits, while PDGF-A polypeptide binds primarily to the alpha subunit. Activation of both receptor subunits may be needed for maximal 
response. IL-1, TNF- $\alpha$ and TGF- $\beta 1$ affect the binding of PDGF [21].

PDGF-BB is probably released by platelets at the wound site during platelet aggregation and is important for normal healing of wounds and fractures (see Table 1). Locally applied PDGF enhances demineralised bone-induced heterotopic osteogenesis in rats [33], healing of tibial osteotomies in rabbits [49] and formation of bone and cement in conventional periodontal surgery in dogs (combined with IGF-I) [44].

\section{FGF}

The FGF family consists of nine members of structurally related polypeptides. Most abundant and best characterised in man are acidic FGF (FGF-1) of 16 $\mathrm{kDa}$ and basic FGF (FGF-2) of $17 \mathrm{kDa}$ [76]. FGF is synthesised by various cells, including monocytes, macrophages, osteoblasts and chondrocytes and affects most mesodermal and neuroectodermal cells. The two FGFs have 55\% structural homology and bind to the same receptor. As opposed to TGF- $\beta 1$, bFGF is stored in matrix in an active form [30]. It probably initiates the normal embryonic limb bud formation [22] and contributes to normal wound [62] and fracture [14] healing (see Table 1).

Jingushi et al. found that repeated injections of aFGF into the fracture-site in rats induced cartilage enlargement and decreased mRNA expression for type II procollagen and proteoglycan core protein [36]. In rats, bFGF enhances demineralised bone-induced heterotopic osteogenesis [7] and the incorporation of bone grafts and porous hydroxyapatite implants [76-78]. Human recombinant aFGF in agarose promotes the healing of rat parietal critical size defects [26].

\section{IGF I-II}

IGF-I (somatomedin-C; $7.5 \mathrm{kDa}$ ) and IGF-II (skeletal growth factor; $8.7 \mathrm{kDa}$ ) are produced by different types of cells, including osteoblasts. IGF-II is the growth factor found in the highest concentration in bone matrix. IGF-I is 4 to 7 times more potent than IGF-II [39]. Cortisol inhibits IGF-I production, whereas PTH, GH, prostaglandin E2 and BMP-2 stimulate IGF-I production in cultured osteoblast-like cells. The biological actions of the IGFs are modulated in a cell-specific manner by six IGF-binding proteins (IGPBP) that are all expressed by osteoblasts. The expression and secretion of both IGFBPs [13] and IGF-I and IGF-II [12] changes during the development sequence of rat osteoblast cultures. IGF-I stimulates bone DNA, collagen and non-collagen protein synthesis in cultures of foetal rat calvaria [20]. IGF-I and IGF-II increase bone collagen synthesis and decrease collagen degradation in intact rat calvaria in vitro [45] and stimulate proliferation of osteoblasts in serum-free cultures of human bone cells [46].
Endothelial and mesenchymal cells expressed IGF-II mRNA at the granulation tissue stage of healing fractures in humans [5]. At the stage of bone and cartilage formation, osteoblasts and non-hypertrophic chondrocytes expressed mRNA for both IGF-I and II. The findings support a role for IGFs in the local cellular regulation in human fracture healing.

IGF is important in demineralised bone-induced heteropic osteogenesis. Prisell et al. found that IGF-I mRNA was expressed in correlation with the recruitment and proliferation of mesenchymal cells, whereas IGF-II mRNA was activated later, at the start of the calcifying process during endochondral bone formation [53]. Yu and co-workers found that an IGF-II (M-6-P) receptor was present in implants from day 1 to day 21; the highest levels were expressed on day 11 during bone differentiation [83].

IGF-I enhanced the healing of experimental defects of the skull [66] and the zygomatic arch [68], the longitudinal growth of diaphyseal bone [69] and induced premature closure of the frontal suture [67] in rats. We found enhanced healing of experimental calvarial defects in rats by polyorthoester membranes for guided tissue regeneration containing IGF-I [19].

\section{Delivery systems}

A system for the delivery of osteo-inducing agents should preserve the shape and bulk of reconstructions and assure local, sustained release of the factors which may otherwise be rapidly absorbed before instituting their effect. Advanced systems (polymers) may allow accurate dosage and combining factors to be delivered concurrently or at different points of time. The ideal material should be biocompatible, be resorbed and replaced by bone within 6 weeks [74] and not inhibit bone formation by inducing a chronic inflammation or physically obstructing bone formation by incomplete resorption.

Several biodegradable materials have been investigated, including (1) organic materials such as inactive demineralized bone proteins, collagen, fibrin sealant, fibrin-collagen paste, squalene and glycerol; (2) ceramics, including $\beta$-tricalcium phosphate and plaster of Paris (calcium sulphate); and (3) synthetic polymers such as polylactic acid [42], polyactide-polyglycolide co-polymer [56], polyanhydride [43] and polyorthoester [51,61].

Some existing delivery systems do not fulfil the above criteria. Unresorbed $\beta$-tricalcium phosphate [74], co-polymer of polylactide-polyglycolide [56] and polylactic acid [42] were detected at 4 months, 24 weeks and 6 months, respectively. Fibrin-collagen paste and fibrin sealant were incompletely absorbed, induced a chronic inflammation and inhibited heterotopic osteoinduction $[52,61]$. We have evaluated the effect of a bioerodible polyorthoester made for sustained delivery on heterotopic [51, 61] and orthotopic [59, 60,63] osteogenesis. The polyorthoester does not inhibit bone formation, it induces 
little tissue reaction and it is mostly resorbed by 4 weeks.

In the near future we will probably be able to treat skeletal defects and pseudarthrosis by implants of growth factors in a resorbable sustained delivery system. However, the prerequisite to such treatment is more knowledge about the importance of various growth factors in the different steps of the osteoinduction cascade and the different stages of impaired bone healing, the relative importance of lack of growth factors as opposed to the lack of osteoprogenitor cells in impaired bone healing, and the characteristics of the ideal biodegradable systems for sustained delivery of osteogenic growth factors.

\section{References}

1. Abdennagy B, Hott M, Marie PJ (1992) Effects of plateletderived growth factor on human and mouse osteoblastic cells isolated from the trabecular bone surface. Cell Biol Int Rep 16:235-247

2. Ahrens M, Ankenbauer T, Schröder D, Hollnagel A, Mayer H, Gross G (1993) Expression of human bone morphogenetic proteins- 2 or -4 in murine mesenchymal progenitor C3H10T1/2 cells induces differentiation into distinct mesenchymal cell lineages. DNA Cell Biol 12:871-880

3. Amedee J, Bareille R, Rouais F, Cunningham N, Reddi H, Harmand M (1994) Osteogenin (bone morphogenic protein 3) inhibits proliferation and stimulates differentiation of osteoprogenitors in human bone marrow. Differentiation 58:157-164

4. Andrew JG, Hoyland J, Andrew SM, Freemont AJ, Marsh D (1993) Demonstration of TGF-beta 1 mRNA by in situ hybridization in normal human fracture healing. Calcif Tissue Int 52:74-78

5. Andrew JG, Hoyland J, Freemont AJ, Marsh D (1993) Insulinlike growth factor gene expression in human fracture callus. Calcif Tissue Int 53:97-102

6. Asahina I, Sampath T, Hauschka P (1996) Human osteogenic protein-1 induces chondroblastic, osteoblastic, and/or adipocytic differentiation of clonal murine target cells. Exp Cell Res 222:38-47

7. Aspenberg P, Lohmander LS (1989) Fibroblast growth factor stimulates bone formation: bone induction studied in rats. Acta Orthop Scand 60:473-476

8. Aspenberg P, Turek T (1996) BMP-2 for intramuscular bone induction: effect in squirrel monkeys is dependent on implantation site. Acta Orthop Scand 67:3-6

9. Aspenberg P, Wang E, Thorngren KG (1992) Bone morphogenetic protein induces bone in the squirrel monkey, but bone matrix does not. Acta Orthop Scand 63:619622

10. Beck LS, Amento EP, Xu Y, Deguzman L, Lee WP, Nguyen T, Gillett NA (1993) TGF-beta 1 induces bone closure of skull defects: temporal dynamics of bone formation in defects exposed to rhTGF-beta 1. J Bone Miner Res 8:753-761

11. Beck LS, Deguzman L, Lee WP, Xu Y, McFatridge LA, Gillett NA, Amento EP (1991) Rapid publication: TGFbeta 1 induces bone closure of skull defects. J Bone Miner Res 6:1257-1265

12. Birnbaum RS, Bowsher RR, Wiren KM (1995) Changes in IGF-I and -II expression and secretion during the proliferation and differentiation of normal rat osteoblasts. J Endocrinol 144:251-259

13. Birnbaum RS, Wiren KM (1994) Changes in insulin-like growth factor-binding protein expression and secretion during the proliferation, differentiation, and mineralization of primary cultures of rat osteoblasts. Endocrinology 135: 223-230

14. Bolander ME (1992) Regulation of fracture repair by growth factors. Proc Soc Exp Biol Med 200:165-170

15. Bonewald LF, Mundy GR (1990) Role of transforming growth factor-beta in bone remodeling. Clin Orthop 250: 261-276

16. Bostrom M, Lane J, Berberian W, Missri A, Tomin E, Weiland A, Doty S, Glaser D, Rosen V (1995) Immunolocalization of expression of bone morphogenetic proteins 2 and 4 in fracture healing. J Orthop Res 13:357-367

17. Bourque WT, Gross M, Hall BK (1993) Expression of four growth factors during fracture repair. Int $\mathrm{J}$ Dev Biol 37:573-579

18. Boyne PJ (1996) Animal studies of application of rhBMP2 in maxillofacial reconstruction. Bone 19 [1 Suppl]: 83S-92S

19. Busch O, Solheim E, Bang G, Tornes K (1996) Guided tissue regeneration and local delivery of insulinlike growth factor I by bioerodible polyorthoester membranes in rat calvarial defects. Int $\mathrm{J}$ Oral Maxillofac Implants 11: 498-505

20. Canalis E (1980) Effect of insulinlike growth factor I on DNA and protein synthesis in cultured rat calvaria. J Clin Invest 66:709-719

21. Canalis E, Varghese S, McCarthy TL, Centrella M (1992) Role of platelet derived growth factor in bone cell function. Growth Regul 2:151-155

22. Cohn MJ, Izpisua-Belmonte JC, Abud H, Heath JK, Tickle C (1995) Fibroblast growth factors induce additional limb development from the flank of chick embryos. Cell 80: 739-746

23. Cook SD, Baffes GC, Wolfe MW, Sampath TK, Rueger DC (1994) Recombinant human bone morphogenetic protein-7 induces healing in a canine long-bone segmental defect model. Clin Orthop 301:302-312

24. Cook SD, Baffes GC, Wolfe MW, Sampath TK, Rueger DC, Whitecloud TS3 (1994) The effect of recombinant human osteogenic protein-1 on healing of large segmental bone defects. J Bone Joint Surg [Am] 76:827-838

25. Cook SK, Wolfe MW, Salkeld SL, Rueger DC (1995) Effect of recombinant human osteogenic protein-1 on the healing of segmental defects in non-human primates. J Bone Joint Surg [Am] 77:734-750

26. Cuevas P, de Paz V, Cuevas B, Marin-Martinez J, PiconMolina M, Fernandez-Pereira A, Gimenez-Gallego G (1997) Osteopromotion for cranioplasty: an experimental study in rats using acidic fibroblast growth factor. Surg Neurol 47:242-246

27. Einhorn T (1995) Enhancement of fracture-healing. J Bone Joint Surg [Am] 77:940-956

28. Gerhart TN, Kirker-Head CA, Kriz MJ, Holtrop ME, Hennig GE, Hipp J, Schelling SH, Wang E (1993) Healing segmental femoral defects in sheep using recombinant human bone morphogenetic protein. Clin Orthop 293: 317-326

29. Gitelman S, Kobrin M, Ye J, Lopez A, Lee A, Derynck R (1994) Recombinant Vgr-/BMP-6-expressing tumors induce fibrosis and endochrondral bone formation in vivo. J Cell Biol 126:1595-1609

30. Gospodarowicz D (1990) Fibroblast growth factor: chemical structure and biological function. Clin Orthop 257: 231-248

31. Harris S, Bonewald L, Harris M, Sabatini M, Dallas S, Feng J, Ghosh-Choudhury N, Wozney J, Mundy G (1994) Effects of transforming growth factor beta on bone nodule formation and expression of bone morphogenetic protein 2, osteocalcin, osteopontin, alkaline phosphatase, and type I collagen mRNA in long-term cultures of fetal rat calvarial osteoblasts. J Bone Miner Res 9:855-863 
32. Helm GA, Sheehan JM, Sheehan JP, Jane JA Jr, diPierro CG, Simmons NE, Gillies GT, Kallmes DF, Sweeney TM (1997) Utilization of type I collagen gel, demineralized bone matrix, and bone morphogenetic protein-2 to enhance autologous bone lumbar spine fusion. J Neurosurg 86:93-100

33. Howes R, Bowness JM, Grotendorst GR, Martin GR, Reddi AH (1988) Platelet-derived growth factor enhances demineralized bone matrix-induced cartilage and bone formation. Calcif Tissue Int 42:34-38

34. Ishidou Y, Kitajima I, Obama H, Maruyama I, Murata F, Imamura T, Yamada N, Ten DP, Miyazono K, Sakou T (1995) Enhanced expression of type I receptors for bone morphogenetic proteins during bone formation. $\mathrm{J}$ Bone Miner Res 10:1651-1659

35. Iwasaki S, Tsuruoka N, Hattori A, Sato M, Tsujimoto M, Kohno M (1995) Distribution and characterization of specific cellular binding proteins for bone morphogenetic protein-2. J Biol Chem 270:5476-5482

36. Jingushi S, Heydemann A, Kana SK, Macey LR, Bolander ME (1990) Acidic fibroblast growth factor (aFGF) injection stimulates cartilage enlargement and inhibits cartilage gene expression in rat fracture healing. J Orthop Res 8: 364-371

37. Joyce ME, Jinguishi S, Bolander ME (1990) Transforming growth factor-beta in the regulation of fracture repair. Orthop Clin North Am 21:199-209

38. Levander G (1938) A study of bone regeneration. Surg Gynecol Obstet 67:705-714

39. Lind M (1996) Growth factors, possible new clinical tools: a review. Acta Orthop Scand 67:407-417

40. Lind M, Overgaard S, Ongpipattanakul B, Nguyen T, Bunger C, Soballe K (1996) Transforming growth factor-beta 1 stimulates bone ongrowth to weight-loaded tricalcium phosphate coated implants: an experimental study in dogs. J Bone Joint Surg [Br] 78:377-382

41. Linde A, Hedner E (1995) Recombinant bone morphogeneitc protein-2 enhances bone healing, guided by osteopromotive e-PTFE membranes: an experimental study in rats. Calcif Tissue Int 56:549-553

42. Lovell TP, Dawson EG, Nilsson OS, Urist MR (1989) Augmentation of spinal fusion with bone morphogenetic protein in dogs. Clin Orthop 243:266-274

43. Lucas PA, Laurencin C, Syftestadt GT, Domb A, Goldberg VM, Caplan AI, Langer R (1990) Ectopic induction of cartilage and bone by water-soluble proteins for bovine bone using a polyanhydride delivery vehicle. J Biomed Mater Res 24:901-911

44. Lynch SE, de Castilla GR, Williams RC, Kiritsy CP, Howell TH, Reddy MS, Antoniades HN (1991) The effects of short-term application of a combination of platelet-derived and insulin-like growth factors on periodontal wound healing. J Periodontol 62:458-467

45. McCarthy TL, Centrella M, Canalis E (1989) Regulatory effects of insulin-like growth factors I and II on bone collagen synthesis in rat calvarial cultures. Endocrinology 124:301-309

46. Mohan S, Baylink DJ (1991) Bone growth factors. Clin Orthop 263:30-48

47. Moxham J, Kibblewhite D, Bruce A, Rigley T, Gillespy T3, Lane J (1996) Transforming growth factor-beta 1 in a guanidine-extracted demineralized bone matrix carrier rapidly closes a rabbit critical calvarial defect. J Otolaryngol 25:82-87

48. Nakase T, Nomura S, Yoshikawa H, Hashimoto J, Hirota S, Kitamura Y, Oikawa S, Ono K, Takaoka K (1994) Transient and localized expression of bone morphogenetic protein 4 messenger RNA during fracture healing. J Bone Miner Res 9:651-659

49. Nash T, Howlett C, Martin C, Steele J, Johnson K, Hicklin D (1994) Effect of platelet-derived growth factor on tibial osteotomies in rabbits. Bone 15:203-208
50. Paralkar VM, Hammonds RG, Reddi AH (1991) Identification and characterization of cellular binding proteins (receptors) for recombinant human bone morphogenetic protein 2B, an iniator of bone differentiation cascade. Proc Natl Acad Sci USA 88:3397-3401

51. Pinholt EM, Solheim E, Bang G, Sudmann E (1991) Bone induction by composite of bioerodible polyorthoester and demineralized bone matrix in rats. Acta Orthop Scand 62:476-486

52. Pinholt EM, Solheim E, Bang G, Sudmann E (1992) Bone induction by composites of bioresorbable carriers and demineralized bone in rats: a comparative study of fibrin-collagen paste, fibrin sealant, and polyorthoester with gentamicin. J Oral Maxillofac Surg 50:1300-1304

53. Prisell PT, Edwall D, Lindblad JB, Levinovitz A, Norstedt G (1993) Expression of insulin-like growth factors during bone induction in rat. Calcif Tissue Int 53:201-205

54. Riley E, Lane J, Urist M, Lyons K, Lieberman J (1996) Bone morphogenetic protein-2: biology and applications. Clin Orthop 324:39-46

55. Schimandle JH, Boden SD, Hutton WC (1995) Experimental spinal fusion with recombinant human bone morphogenetic protein-2. Spine 20:1326-1337

56. Schmitz JP, Hollinger JO (1988) A preliminary study of the osteogenic potential of a biodegradable alloplastic-osteoinductive alloimplant. Clin Orthop 237:245-255

57. Sellers RS, Peluso D, Morris EA (1997) The effect of recombinant human bone morphogenetic protein-2 (rhBMP2 ) on the healing of full-thickness defects of articular cartilage. J Bone Joing [Am] 79:1452-1463

58. Shimizu K, Yoshikawa H, Takaoka K (1995) Local effects of bone morphogenetic protein-4 on skeletal tissues. Clin Orthop 318:243-250

59. Solheim E, Pinholt EM, Andersen R, Bang G, Sudmann E (1992) The effect of a composite of polyorthoester and demineralized bone on the healing of large segmental defects of the radius in rats. J Bone Joint Surg [Am] 74:1456-1463

60. Solheim E, Pinholt EM, Bang G, Sudmann E (1992) Regeneration of calvarial defects by a composite of bioerodible polyorthoester and demineralized bone in rats. J Neurosurg 76:275-279

61. Solheim E, Pinholt EM, Bang G, Sudmann E (1992) Effect of local hemostatics on bone induction in rats: a comparative study of bone wax, fibrin-collagen paste, and bioerodible polyorthoester with and without gentamicin. J Biomed Mater Res 26:791-800

62. Steenfos HH (1994) Growth factors and wound healing. Scand J Plast Reconstr Surg Hand Surg 28:95-105

63. Sudmann B, Anfinsen O-G, Bang G, Koppang R, Stølen SO, Koppang HS, Sudmann E (1993) Assessment in rats of a new bioerodible bone-wax-like polymer. Acta Orthop Scand 64:336-339

64. Sumner D, Turner T, Purchio A, Gombotz W, Urban R, Galante J (1995) Enhancement of bone ingrowth by transforming growth factor-beta. J Bone Joing Surg [Am] $77: 1135-1147$

65. Tanaka T, Taniguchi Y, Gotoh K, Satoh R, Inazu M, Ozara H (1993) Morphological study of recombinant human transforming growth factor beta 1-induced intramembranous ossification in neonatal rat parietal bone. Bone 14:117-123

66. Thaller SR, Dart A, Tesluk H (1993) The effects of insulin-like growth factor-1 on critical-size calvarial defects in Sprague-Dawley rats. Ann Plast Surg 31:429-433

67. Thaller SR, Hoyt J, Tesluk H, Holmes R (1993) The effect of insulin growth factor-1 on calvarial sutures in a Sprague-Dawley rat. J Craniofac Surg 4:35-39

68. Thaller SR, Hoyt J, Tesluk H, Holmes R (1993) Effect of insulin-like growth factor-1 on zygomatic arch bone regeneration: a preliminary histological and histometric study. Am Plast Surg 31:421-428 
69. Tobias JH, Chow JW, Chambers TJ (1992) Opposite effects of insulin-like growth factor-I on the formation of trabecular and cortical bone in adult female rats. Endocrinology 131:2387-2392

70. Toriumi DM, Kotler HS, Luxenberg DH, Holtrop ME, Wang EA (1991) Mandibular reconstruction with a recombinant bone-inducing factor. Functional, histologic, and biomechanical evaluation. Arch Otolaryngol Head Neck Surg 117:1101-1112

71. Trippel SB, Coutts RD, Einhorn TA, Mundy GR, Rosenfeld RG (1996) Growth factors as therapeutic agents. J Bone Joint Surg [Am] 78(8):1272-1286

72. Urist MR (1965) Bone: formation by autoinduction. Science 150:893-899

73. Urist MR, Mikulski A, Lietze A (1979) Solubilized and insolubilized bone morphogenetic protein. Proc Natl Acad Sci USA 76:1828-1832

74. Urist MR, Nilsson O, Rasmussen J, Hirota W, Lovell T, Schmalzreid T, Finerman GA (1987) Bone regeneration under the influence of a bone morphogenetic protein (BMP) beta tricalcium phosphate (TCP) composite in skull trephine defects in dogs. Clin Orthop 214:295-304

75. Wang EA, Rosen V, D'Alessandro JS, Bauduy M, Cordes P, Harada T, Israel DI, Hewick RM, Kerns KM, LaPan P et al. (1990) Recombinant human bone morphogenetic protein induces bone formation. Proc Natl Acad Sci USA $87: 2220-2224$
76. Wang JS (1996) Basic fibroblast growth factor for stimulation of bone formation in osteoinductive or conductive implants. Acta Orthop Scand [Suppl] 269:1-33

77. Wang JS, Aspenberg P (1994) Basic fibroblast growth factor increases allograft incorporation. Bone chamber study in rats. Acta Orthop Scand 65:27-31

78. Wang JS, Aspenberg P (1996) Basic fibroblast growth factor enhances bone-graft incorporation: dose and time dependence in rats. J Orthop Res 14:316-323

79. Wozney JM (1992) The bone morphogenetic protein family and osteogenesis. Mol Reprod Dev 32:160-167

80. Wozney JM, Rosen V, Celeste AJ, Mitsock LM, Whitters MJ, Kriz RW, Hewick RM, Wang EA (1988) Novel regulators of bone formation: molecular clones and activities. Science 242:1528-1534

81. Yamaguchi A, Ishizuya T, Kintou N, Wada Y, Katagiri T, Wozney J, Rosen V, Yoshiki S (1996) Effects of BMP-2, BMP-4, and BMP-6 on osteoblastic differentiation of bone marrow-derived stromal cell lines, ST2 and MC3T3G2/PA6. Biochem Biophys Res Commun 220:366-371

82. Yasko AW, Lane JM, Fellinger EJ, Rosen V, Wozney JM, Wang EA (1992) The healing of segmental bone defects, induced by recombinant human bone morphogenetic protein (rhBMP-2). A radiographic, histological, and biomechanical study in rats. J Bone Joint Surg [Am] 74:659-670

83. Yu YM, Sklar MM, Nissley SP, Reddi AH (1993) Changes in the expression of insulin-like growth factor II/mannose6-phosphate receptor during endochondral bone development. Biochem Biophys Res Commun 195:516-524 